dramatic fall in pulmonary artery pressure, the patient might fulfil the responder criteria (fall in mean pulmonary artery pressure by $>10 \mathrm{mmHg}$ to $<40 \mathrm{mmHg}$ in the presence of a cardiac output), and may, therefore, be a candidate for treatment with calcium channel blockers [1].

I agree with A.H. Morice and coworkers that the relatively short half-life of sildenafil (3-4 h) may be a drawback of this drug. Patients' compliance may rarely be an issue. However, the fluctuations in sildenafil plasma concentrations are poorly tolerated by some patients. A drug with a much longer halflife, such as tadalafil $(\sim 18 \mathrm{~h})$, might be advantageous, but caution is necessary. GHOFRANI et al. [2] have demonstrated substantial variability in the haemodynamic effects of several phosphodiesterase- 5 inhibitors. For the time being, there is a strong body of evidence for the safety and efficacy of sildenafil in pulmonary arterial hypertension, but there is a lack of comparable data for other phosphodiesterase- 5 inhibitors, such as tadalafil.

\section{M.M. Hoeper}

Dept of Respiratory Medicine, Hannover Medical School, Hannover, Germany.

\section{REFERENCES}

1 Galie N, Torbicki A, Barst R, et al. Guidelines on diagnosis and treatment of pulmonary arterial hypertension. The Task Force on Diagnosis and Treatment of Pulmonary Arterial Hypertension of the European Society of Cardiology. Eur Heart J 2004; 25: 2243-2278.

2 Ghofrani HA, Voswinckel R, Reichenberger F, et al. Differences in hemodynamic and oxygenation responses to three different phosphodiesterase-5 inhibitors in patients with pulmonary arterial hypertension: a randomized prospective study. J Am Coll Cardiol 2004; 44: 1488-1496.

\title{
Efficacy of fluticasone on cough
}

\section{To the Editors:}

In the original article by PONSIOEN et al. [1], there is no mention of the predictive value of the type of airway inflammation that is associated with cough, or whether there was any benefit from inhaled corticosteroid treatment.

There is increasing evidence that eosinophilic airway inflammation, i.e. an eosinophilic bronchitis, which can be identified from spontaneous or induced sputum cell counts, predicts the benefit from corticosteroid treatment in chronic cough, asthma and chronic obstructive pulmonary disease and that a lack of eosinophilia indicates an absence of any benefit [2-6].

An eosinophilic bronchitis occurs in only $10-30 \%$ of patients referred to a specialist with an isolated chronic cough [7-9]. Hence, in an unselected population of patients with cough, the majority of whom will not have eosinophilic bronchitis, the benefit from inhaled steroid treatment is likely to be small, as indicated in the study by PONSIOEN et al. [1], or absent. Measurement of airway inflammation is necessary to interpret the results of treatment with anti-inflammatory medications.

\section{F. Hargreave and K. Parameswaran}

Firestone Institute for Respiratory Health, McMaster University and St. Joseph's HealthCare, Hamilton, ON, Canada.

\section{REFERENCES}

1 Ponsioen BP, Hop WCJ, Vermue NA, Dekhuijzen PNR, Bohnen AM. Efficacy of fluiticasone on cough: a randomised controlled trial. Eur Respir J 2005; 145: 147-152.

2 Gibson PG, Dolovich J, Denburg J, Ramsdale EH, Hargreave FE. Chronic cough: eosinophilic bronchitis without asthma. Lancet 1989; 17: 1346-1348.
3 Pavord ID, Brightling CE, Wolkman G, Wardlaw AJ. Noneosinophilic corticosteroid unresponsive asthma. Lancet 1999; 353: 2213-2214.

4 Pizzichini E, Pizzichini MM, Gibson P, et al. Sputum eosinophilia predicts benefit from prednisone in smokers with chronic obstructive bronchitis. Am J Respir Crit Care Med 1998; 158: 1511-1517.

5 Brightling CE, Monteiro W, Ward R, et al. Sputum eosinophilia and short-term response to prednisolone in chronic obstructive pulmonary disease: a randomized controlled trial. Lancet 2000; 365: 1480-1485.

6 Pizzichini MM, Pizzichini E, Parameswaran K, et al. Nonasthmatic chronic cough: no effect of treatment with an inhaled corticosteroid in patients without sputum eosinophilia. Can Respir J 1999; 6: 323-330.

7 Brightling CE, Ward R, Goh KL, Wardlaw AJ, Pavord ID. Eosinophilic bronchitis is an important cause of cough. Am J Respir Crit Care Med 1999; 160: 406-410.

8 Carney IK, Gibson PG, Murnee-Allen K, Saltos N, Olson LG, Hensley MJ. A systematic evaluation of mechanisms in chronic cough. Am J Respir Crit Care Med 1997; 156: 211-216.

9 Ayik SO, Basoglu OK, Erdinc M, Bor S, Veral A, Bilgen A. Eosinophilic bronchitis as a cause of chronic cough. Respir Med 2003; 97: 695-701.

DOI: 10.1183/09031936.05.00023205

From the authors:

We would like to thank F. Hargreave and K. Parameswaran for their suggestion that sputum eosinophils and the provocative dose causing a $20 \%$ fall in forced expiratory volume in one 